\title{
Determination of Peak Hours And Level Of Service At An Unsignalised Intersection Using aa SIDRA 2.0
}

\author{
Mohd Sani Said \\ Department of General Studies, Kota Bharu Polytechnic 16450 Ketereh, Kelantan, Malaysia
}

\begin{abstract}
Unsignalised intersection is one of the most common element in road network systems and is normally implemented to regulate low volume of traffic flow. Unlike a signalised intersection, it can operate without heavy investment on the equipment, operations and maintenance. Therefore, it is crucially important for an unsignalised intersection to operate at the best Level of Service (LOS) possible and the lowest possible Degree of Saturation, Control Delay and Queue Length. In this study, aaSIDRA 2.0 software package was applied in analyzing the collected data. Peak hours were determined by the means of traffic counts. The aaSIDRA 2.0 programme requires the Peak Hour Factor (PHF) to be the key variable for the analysis. The software was then applied to get the LOS of the roads affected as well as the overall LOS of the intersection. The area chosen for the study was the Kota Bharu-Machang Road and Jalan Pangkal Kalong Intersection, located about 24 kilometres south of Kota Bharu town in the state of Kelantan, Malaysia. This particular intersection has seen an increase in traffic volume in the last ten years, culminating in delays and congestions. Results of this preliminary study have shown that the peak hours were from 7.00 a.m. to 8.00 a.m. and 4.00 p.m. to 6.00 p.m. As for the level of service (LOS), it is graded at LOS F which indicates the need for a signalized intersection.
\end{abstract}

Keywords: Intersection, Unsignalised, Peak Hour, Level of Service.

\section{Introduction}

'Unsignalised' in traffic engineering simply means 'without the use of traffic signal lights' and 'intersection' is defined as 'the place where two or more roads meet'. Unsignalized intersection is implemented to regulate low volume of traffic flow. According to [1] 'unsignalized intersections' can be defined as intersections with stop signs, intersections where signals are no longer functioning (e.g due to loss of power) or intersections where the driver must judge whether stopping is appropriate (e.g at intersections without any traffic control). Since 'unsignalised intersection' is almost the simplest form of intersection in a road network, there were past researches about the topic focusing mostly on factors such as speed, accident and transportation. One of the main weaknesses of an unsignalised intersection is that there is minimal positive indication for the driver to leave or enter an intersection. [2] stated that to enter an unsignalised intersection, the driver looks for a safe opportunity or "gap" in the traffic. This technique is commonly known as 'Gap Acceptance'. Studies by [3] have found that the majority of high frequency intersection crashes occurred during clear conditions and in daylight, (where the traffic volumes and delays are greater) probably due to drivers accepting smaller traffic gaps.

\section{Aa SIDRA Software Package}

SIDRA or "Signalised or Unsignalised Intersection Design and Research Aid" is a software that can analyse signalised and unsignalised intersections including roundabouts in one package [4]. It is an advanced micro-analytical traffic evaluation tool that employs lane-by-lane and vehicle drive cycle models as well the tool for evaluation of alternative intersection designs in terms of capacity, level of service, a wide range of performance measures including delay, queue length, stops, fuel consumption, pollutant emissions and operating cost. It can also perform signal timing optimization for actuated and fixed-time signals with simple to most sophisticated signal phasing schemes. aaSIDRA software package has been used to evaluate signalized and unsignalized intersections and roundabouts by a number of researchers [5], [6], [7]. 


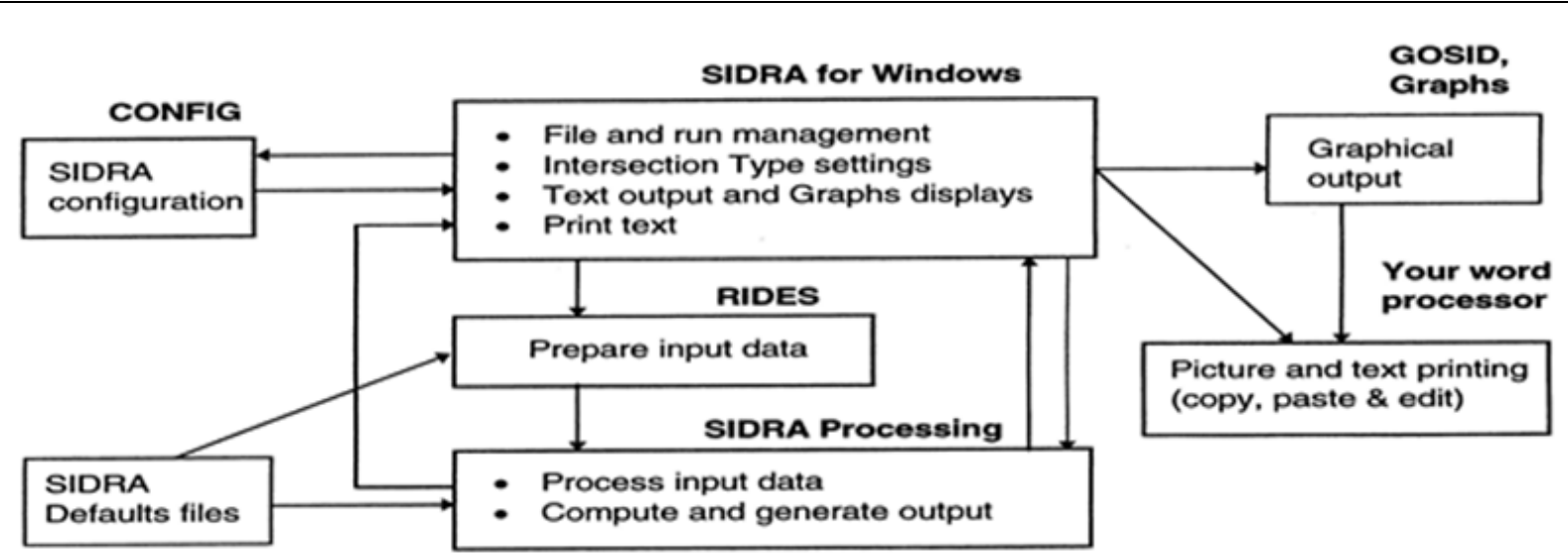

Figure 1. Summary of SIDRA Operation

\section{Problem Statement}

The unsignalised Km 27 Kok Lanas intersection has been observed as having long queues and delays, especially for vehicles coming from Pangkal Kalong and those from Kota Bharu. This normally happens during peak hours around 8.00 in the morning and around 4.30 in the evening. The long queues along Jalan Kota Bharu occur as a result of the vehicles having to wait for the car in front to make its right turn into Pangkal Kalong since the road is a single lane per direction. The through traffic movement from Machang to Kota Bharu is normally fast and heavy that makes it difficult for the vehicles coming from Kota Bharu to pass through the gap when turning into Pangkal Kalong. Similarly, vehicles coming from Pangkal Kalong have difficulties to turn left into Kota Bharu because of the heavy traffic coming from Machang. The worse condition is when there are vehicles making right turns into Machang whereby they have to cross through the gap among the vehicles coming from Kota Bharu as well as the gap among the vehicles coming from Machang simultaneously (Fig. 2). Traditional solutions to overcome traffic congestions at intersections were to build traffic signs separating major and minor roads. However, the growth of the motorization and the increase in the number of vehicle users lead to the need of other options for more effective controls. In constructing or reconstructing an intersection, traffic engineers have to make a responsible decision about the type and technical parameters of the future junction. Thus, a preliminary study was conducted to justify the need for a signalized intersection

\section{Objectives Of The Study}

This study was conducted to identify the morning and evening peak hours and level of service at an unsignalised ' $\mathrm{T}$ ' intersection in the state of Kelantan, Malaysia. The 'unsignalised' intersection or the intersection 'without traffic lights' was chosen because it constitutes a majority of all intersections in Malaysia, especially in rural areas. For this study, an intersection at Km 24 Kota Bharu-Machang Road was chosen because of the frequent delays and congestions due to the increase in traffic volume.

Specifically, this preliminary study was conducted to:

- Identify the Morning and Evening Peak Hours at the Kota Bharu-Machang-Pangkal Kalong junction;

- Determine the current Level of Service (LOS) of the junction

\subsection{Study Area}

\section{Methodology}

The intersection chosen for the study was confined to an unsignalised junction at Kok Lanas along the Kota Bharu - Machang main road. The minor road is a $300-\mathrm{cm}$ width lane road called Jalan Pangkal Kalong. In this study, the main road is called Jalan Kota Bharu-Machang because Machang, which is about 17 kilometres from the chosen site is another major town in Kelantan which is located between Kota Bharu and Kuala Krai. During peak hours, some road users were observed to be using alternative routes heading from either north to south or south to north to avoid the delay and congestion at the Jalan Kota Bharu - Machang and Jalan Pangkal Kalong intersection.

The junction is somewhat surrounded and squeezed by rows of shophouses (see Fig. 2). The lane of the main road (Jalan Kota Bharu - Machang) is $330 \mathrm{~cm}$ wide and the minor road ( Jalan Pangkal Kalong) is $300 \mathrm{~cm}$. The shops along the west side of the main road are about five metres from the main road. This limits the motorists' sight distance when exiting Pangkal Kalong and turning either left to Kota Bharu or right towards Machang. 

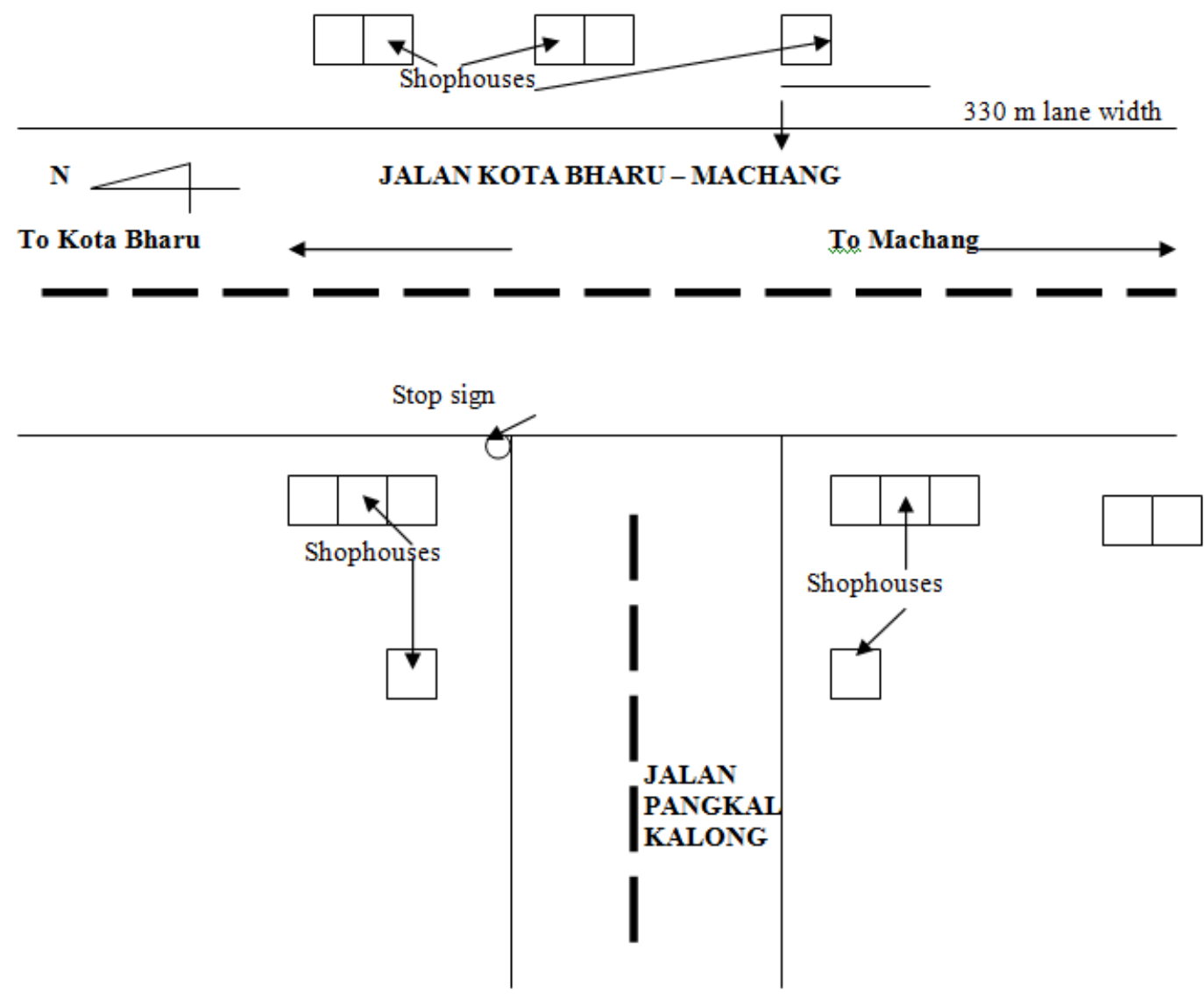

Figure 2. Schematic Map of Jalan Kota Bharu - Machang and Jalan Pangkal Kalong Intersection

\subsection{Traffic Count (A.M and P.M Peak Hour)}

Traffic study was carried out during a typical workday where peak durations were spotted in the morning (AM Peak) and afternoon (PM Peak). The highest flow (pcu/hr) in the morning is the AM Peak whereas the highest flow (pcu/hr) in the evening is the PM Peak.

\subsection{Current Level of Service (LOS)}

The Level of Service or LOS is determined by keying in the data into the aaSIDRA 2.0 program. Six LOS are defined for each type of facility where letters (A to F) are designated for each level. LOS A represents the best operating conditions while LOS F the worst operating conditions. The service flow rates are based on a 15 -min period. The current LOS of the intersection is determined using the aaSidra2.0 software. A current LOS of LOS C or D, for example, would indicate the need for an improvement on the geometry of the junction such as adding lanes and providing medians and short lanes. These results could be evaluated by analyzing the output degree of saturation, delay, queue distance or other parameters which differ significantly from the current unimproved intersection. However, if the present LOS is at LOS F, a decrease or increase in traffic volume could be applied in stages by changing the PHF value in Sensitivity Analysis. The output of each increment is analysed to see the difference in the degree of saturation, delay and queue distance. The flow chart for the main activities is shown in Figure 3.

\subsection{Peak Hour}

\section{Results}

Data was collected on a Tuesday (counting day) at a point on the Kota Bharu-Machang main road about 500 metres from the junction where the traffic was heading towards both directions. The completed field worksheet taken during the counts along Kota Bharu-Machang Road is displayed in Table 1, Fig. 4 and Fig. 5. For the purpose of using the data to provide the input to be entered into the aaSidra 2.0 programme, the data entered was changed to passenger car equivalent unit (pcu). As shown in Fig. 4, the peak hour for the day of the traffic counts was from 7.00 a.m. to 8.00 a.m and 4.00 p.m. to 6.00 p.m. Table 1 shows the type of vehicles recorded on counting day. Traffic count was also carried out the next day from 7.00 a.m to 9.00 a.m and from 4.00 p.m to 6.00 p.m (Table 3). This was done as a measure of checking and comparing the data collected during the peak hours. 


\subsection{Level of Service (LOS)}

The Level of Service (LOS) was obtained by processing the current intersection data. The key element entered into 'Basic Parameters' section of the aaSidra 2.0 programme was the Peak Hour Factor (PHF) value. This value was calculated and obtained as 0.738 . Based on the analysis using aaSidra 2.0, the average LOS of the intersection was at LOS F whilst the through and right turn movement at the intersection for Kota Bharu bound road were at LOS E; the through and left turn movement for Machang-bound road were at LOS A and the left and right turns for Pangkal Kalong-bound road were at LOS F (see Table 4). The output summary of the present unsignalised intersection showed that with the capacity of $3915 \mathrm{veh} / \mathrm{hr}$, the $95 \%$ Back of Queue is at $5.618 \mathrm{~km}$ or 802.5 vehicles and Average Control Delay is $130.5 \mathrm{~s} / \mathrm{veh}$. Using aaSidra 2.0, the current Level of Service was identified to be averaging at LOS F, with one leg of the intersection operating at LOS A, one leg at LOS E and another leg at LOS F.

\section{Conclusions}

The Kota Bharu-Machang Road and Jalan Pangkal Kalong Intersection needs sound solutions to reduce the Delay and Queue Length as well as to improve the Level of Service. This preliminary study has managed to determine the Morning Peak Hour and Evening Peak Hour based on traffic counting. The data collected was used to get the Peak Hour Factor (PHF), a crucial factor to be used throughout the whole analysis using aaSIDRA 2.0. The Peak Hour Factor was used as a variable to study the behaviour of the unsignalised intersection due to the PHF variation. The aaSIDRA 2.0 software is therefore useful in analyzing congestion problems at intersections and based on the results of this study, the Jalan Pangkal Kalong intersection should be a signalized intersection.

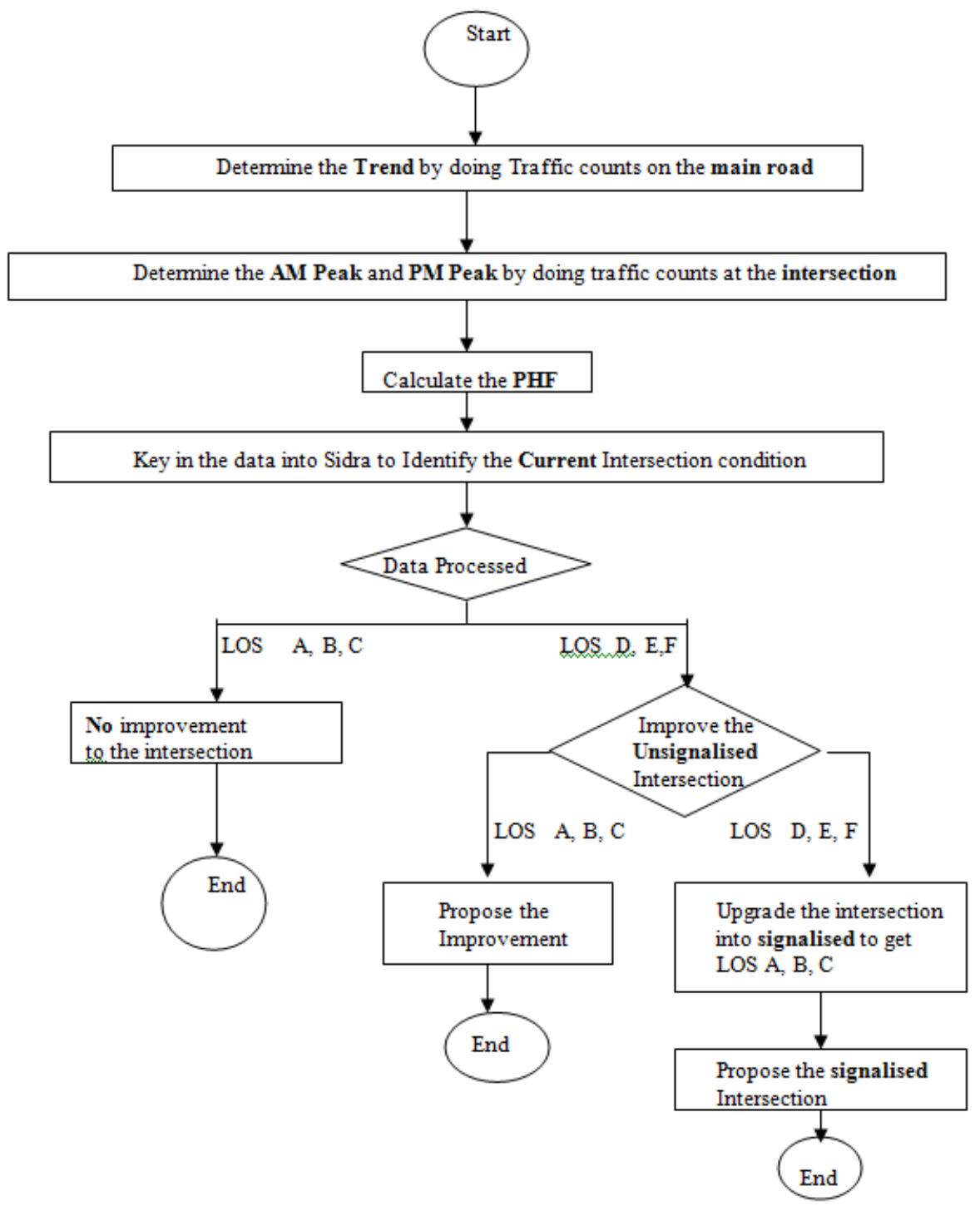

Figure 3. Flow Chart of Main Activities 


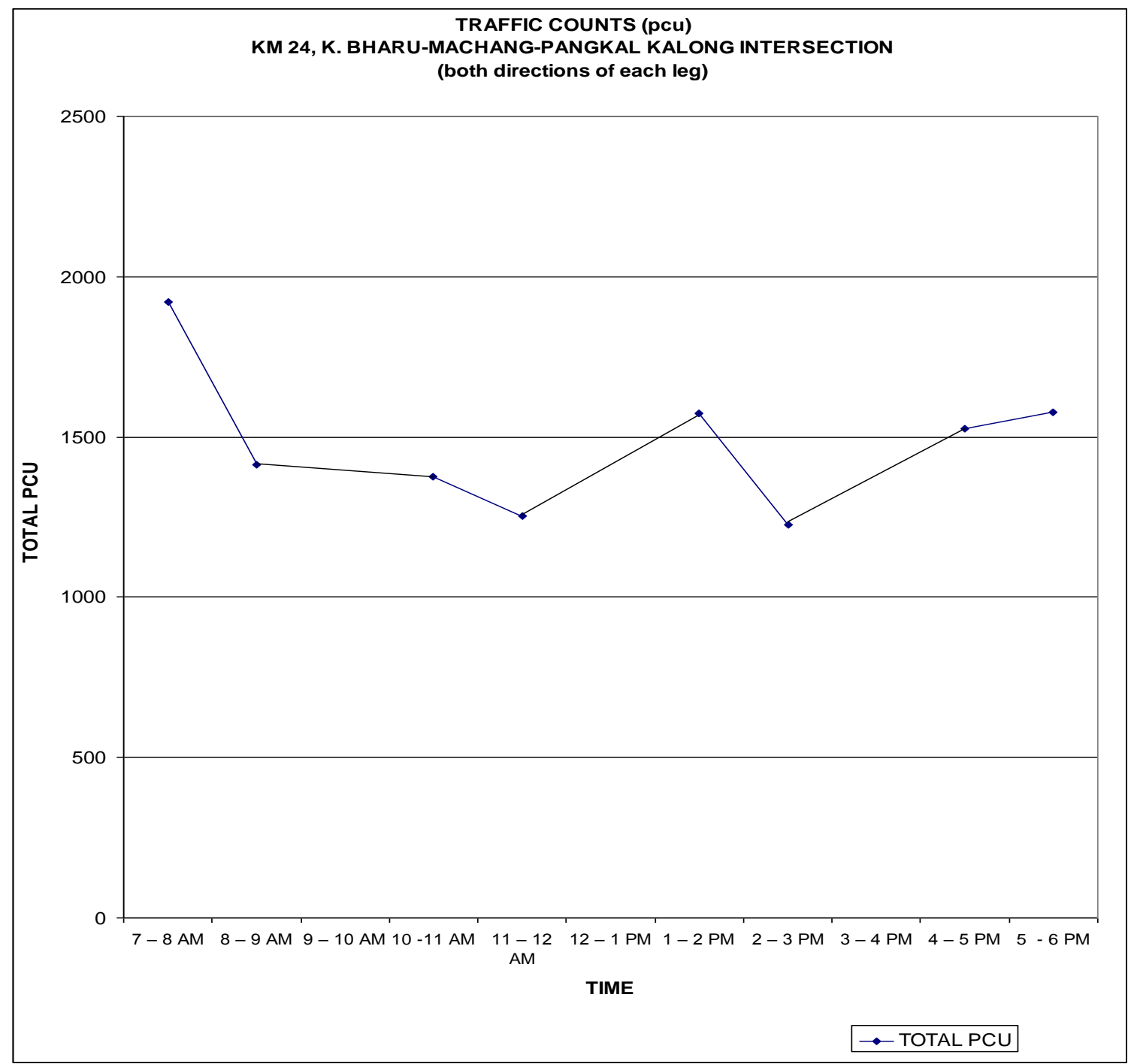

Figure 4. Traffic Count (pcu) Along Kota Bharu-Machang Road - Pangkal Kalong Intersection

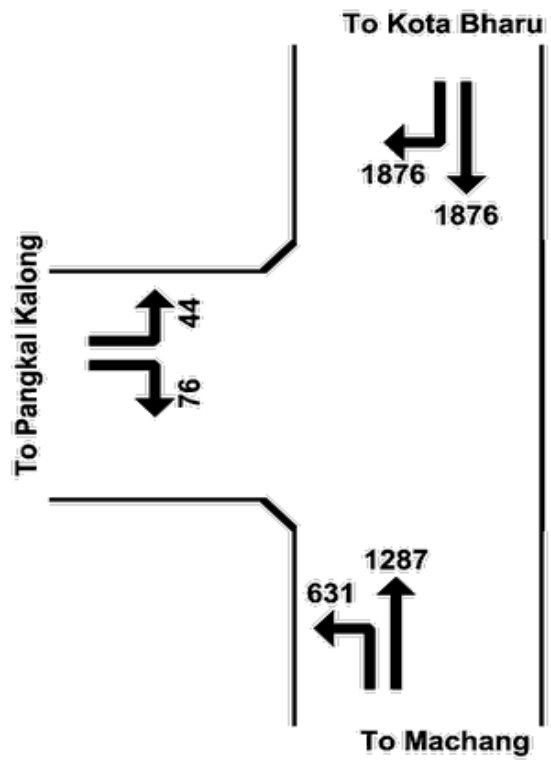

Figure 5. The Total Traffic Capacity (vehicle/hour) of Every Direction at the Kota Bharu - Machang Road and Jalan Pangkal Kalong Intersection as Displayed in the Output of aaSidra 2.0 
Determination of Peak Hours And Level Of Service At An Unsignalised Intersection Using ....

Table 1. Types of vehicles for both directions along Kota Bharu - Machang Road

\begin{tabular}{|c|c|c|c|c|c|c|}
\hline \multirow[b]{2}{*}{ TIME } & \multicolumn{5}{|c|}{ VEHICLE TYPE } & \multirow{3}{*}{$\begin{array}{l}\text { TOTAL } \\
2403\end{array}$} \\
\hline & MOTORCYCLE & CAR & ALL VEHICLES & TRAILER/LORRY & BUS & \\
\hline 7 - 8 A.M. & 705 & 1331 & 259 & 90 & 18 & \\
\hline 8-9 A.M. & 394 & 542 & 174 & 91 & 12 & 1213 \\
\hline 9-10 A.M. & & & BREAK & & & \\
\hline 10-11 A.M. & 333 & 710 & 299 & 104 & 10 & 1456 \\
\hline 11- 12 P.M & 338 & 699 & 296 & 95 & 17 & 1445 \\
\hline 12-1 P.M. & & & BREAK & & & \\
\hline 1 - 2 P.M. & 402 & 825 & 304 & 94 & 16 & 1641 \\
\hline 2 - 3 P.M. & 397 & 879 & 205 & 60 & 12 & 915 \\
\hline 3 - 4 P.M. & & & BREAK & & & \\
\hline 4-5 P.M. & 367 & 679 & 174 & 46 & 19 & 1285 \\
\hline 5 - 6 P.M. & 460 & 837 & 155 & 76 & 17 & 1545 \\
\hline & & & & TOTAL & & 11903 \\
\hline
\end{tabular}

Table 2. Traffic Flow (number of vehicles) at the Intersection

\begin{tabular}{|c|c|c|c|c|c|}
\hline \multicolumn{2}{|c|}{ To Pangkal Kalong } & \multicolumn{2}{|c|}{ To Kota Bharu } & \multicolumn{2}{c|}{ To Machang } \\
\hline 1 & 2 & 3 & 4 & 5 & 6 \\
\hline 44 veh. & 76 veh. & 1876 veh. & 1876 veh. & 631 veh. & 1287 veh. \\
\hline
\end{tabular}

KOTA BHARU - MACHANG ROAD

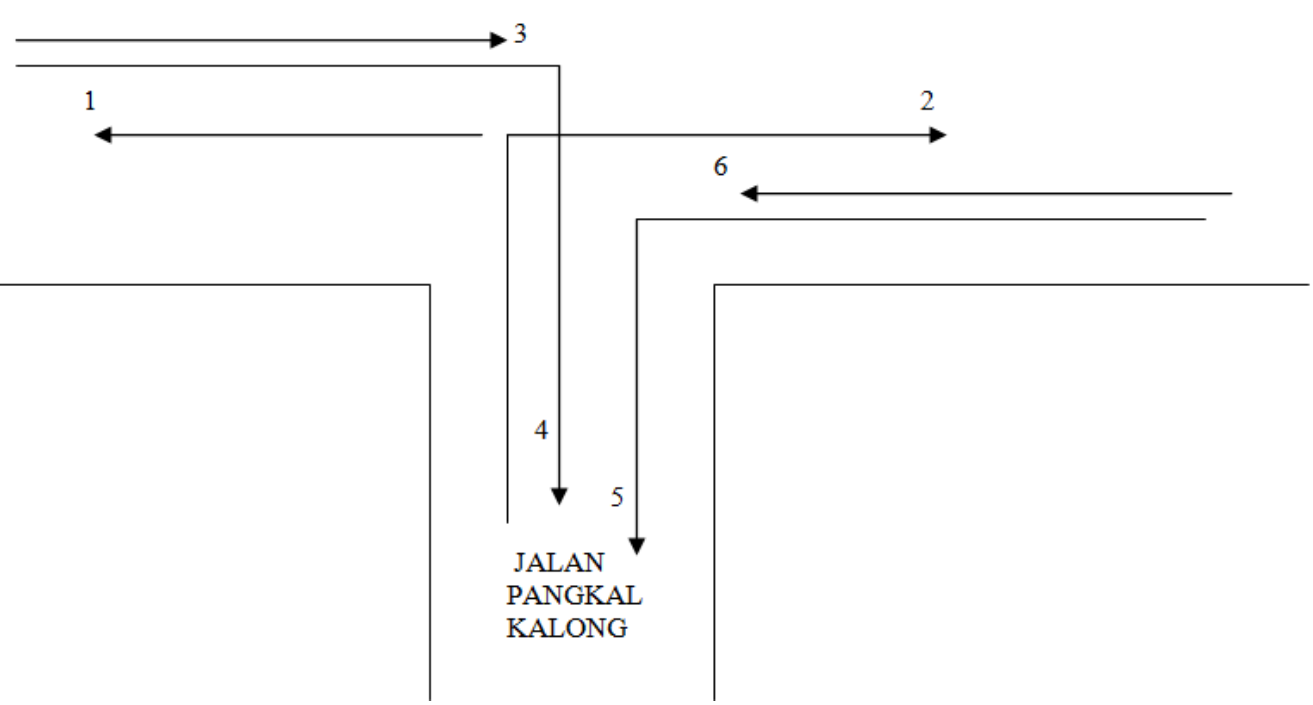

Table 3. Summary of Traffic Counts at the Priority Junction (pcu count per turn/direction per hour)

\begin{tabular}{|c|c|c|c|c|c|c|c|}
\hline TIME & $\begin{array}{c}\text { Machang- } \\
\text { K.Bharu }\end{array}$ & $\begin{array}{c}\text { Machang- } \\
\text { P.Kalong }\end{array}$ & $\begin{array}{c}\text { K.Bharu- } \\
\text { Machang }\end{array}$ & $\begin{array}{c}\text { K.Bharu- } \\
\text { P.Kalong }\end{array}$ & $\begin{array}{c}\text { P.Kalong- } \\
\text { K.Bharu }\end{array}$ & $\begin{array}{c}\text { P.Kalong- } \\
\text { Machang }\end{array}$ & $\begin{array}{c}\text { Total } \\
\text { pcu }\end{array}$ \\
\hline 7-8 AM & 617 & 303 & 1533 & 12 & 74 & 127 & 2666 \\
\hline 8-9 AM & 724 & 145 & 541 & 16 & 63 & 83 & 1572 \\
\hline 4-5 PM & 772 & 83 & 484 & 32 & 53 & 49 & 1473 \\
\hline $5-6$ PM & 820 & 129 & 566 & 33 & 64 & 61 & 1673 \\
\hline
\end{tabular}

Table 4. The Output Movement Summary of the Present Unsignalised Intersection (Movement and the Current LOS, v/c ratio, Queue, Delay etc.)

\begin{tabular}{|c|c|c|c|c|c|c|c|c|c|c|}
\hline $\begin{array}{c}\text { Mov } \\
\text { No }\end{array}$ & Turn & $\begin{array}{c}\text { Dem } \\
\text { Flow } \\
\text { (veh/h) }\end{array}$ & $\begin{array}{c}\text { Cap } \\
(\operatorname{veh} / h)\end{array}$ & $\begin{array}{c}\text { Deg of } \\
\text { Satn } \\
(v / c)\end{array}$ & $\begin{array}{c}\text { Aver Delay } \\
\text { (sec) }\end{array}$ & $\begin{array}{c}\text { Level } \\
\text { of } \\
\text { Service }\end{array}$ & $\begin{array}{c}95 \% \\
\text { Back of } \\
\text { Queue } \\
\text { (m) }\end{array}$ & Eff. Stop Rate & $\begin{array}{c}\text { Aver } \\
\text { Speed } \\
(\mathbf{k m} / \mathbf{h})\end{array}$ & $\begin{array}{l}\text { Oper } \\
\text { Cost } \\
(\$ / h)\end{array}$ \\
\hline \multicolumn{11}{|c|}{ To Machang } \\
\hline 1 & $\mathrm{~L}$ & 409 & 631 & 0.648 & 9.0 & LOS A & 0 & 0.70 & 48.0 & 142 \\
\hline 2 & $\mathrm{~T}$ & 834 & 1287 & 0.648 & 0.0 & LOS A & 0 & 0.00 & 60.0 & 220 \\
\hline \multicolumn{2}{|c|}{ Approach } & 1243 & 1918 & 0.648 & 3.0 & LOS A & & 0.23 & 55.5 & 362 \\
\hline \multicolumn{11}{|c|}{ To Kota Bharu } \\
\hline 8 & $\mathrm{~T}$ & 2072 & 1876 & 1.113 & 65.5 & LOS F & 893 & 0.02 & 21.4 & 1467 \\
\hline
\end{tabular}

DOI: $10.9790 / 1684-1305075359$

www.iosrjournals.org

58 | Page 
Determination of Peak Hours And Level Of Service At An Unsignalised Intersection Using ....

\begin{tabular}{|c|c|c|c|c|c|c|c|c|c|c|}
\hline 8 & $\mathrm{R}$ & 16 & 1876 & 1.113 & 65.5 & LOS F & 893 & 0.02 & 21.4 & 1467 \\
\hline \multicolumn{2}{|c|}{ Approach } & 2088 & 1876 & 1.113 & 65.5 & LOS F & 893 & 0.02 & 21.4 & 1467 \\
\hline \multicolumn{11}{|c|}{ To Pangkal Kalong } \\
\hline 10 & $\mathrm{~L}$ & 100 & 44 & 2.273 & 1211.9 & LOS F & 5618 & 1.05 & 1.7 & 783 \\
\hline 11 & $\mathrm{R}$ & 172 & 76 & 2.263 & 1211.6 & LOS F & 5618 & 1.04 & 1.7 & 1346 \\
\hline \multicolumn{2}{|c|}{ Approach } & 272 & 120 & 2.267 & 1211.7 & LOS F & 5618 & $\mathbf{1 . 0 5}$ & 1.7 & 2129 \\
\hline \multicolumn{2}{|c|}{ All Vehicles } & 3603 & 3915 & 2.273 & 130.5 & LOS F & 5618 & 0.17 & 13.1 & 3958 \\
\hline
\end{tabular}

\section{References}

[1]. J.D. Chovan, L.Tijerina, J.A. Pierrowicz, and D.L. Hendricks. Examination of Unsignalized Intersection, Straight Crossing Path Crashes and Potential IVHS Countermeasures. U.S. Department of Transportation National Highway Traffic Safety Administration Final Report August 1994. Available from http://ntl.bts.gov/lib/jpodocs/repts te/7824.pdf

[2]. R.J. Troutbeck, and W. Brilon. (1992). Unsignalized Intersection Theory. Available from http://www.tongji.edu.cn/ yangdy/its/tft/chap8.pdf

[3]. O. Arndt. Relationship Between Unsignalised Intersection Geometry and Accident Rates. PhD Thesis, Queensland University of Technology, Brisbane, Australia, 2004.

[4]. R. Akcelik, and M. Besley. SIDRA 5 User Guide. ARRB Transport Research Ltd, 1999.

[5]. A. Polus, and E. Vlahos. (2005). Evaluation of Roundabouts versus Signalized and Unsignalized Intersections in Delaware. Available from http://sites.udel.edu/dct/files/2013/10/Rpt.-179-Roundabouts-Final-11329b7.pdf

[6]. Y. Darma, M.R. Karim, J. Mohamad, and S. Abdullah. Control Delay Variability at Signalized Intersection Based on HCM Method. Proceedings of the Eastern Asia Society for Transportation Studies, 2005, 945 - 958.

[7]. P. Ranjitkar, A. Shahin, and F. Shirwali. Evaluating Operational Performance of Intersections Using SIDRA. The Open Transportation Journal, 8, 2014, 50-61. 